\title{
Cytotoxic effects of curcumin in osteosarcoma cells
}

This article was published in the following Dove Press journal:

International Journal of Nanomedicine

14 November 2014

Number of times this article has been viewed

JM Moran

FJ Rodriguez-Velasco

R Roncero-Martin

V Vera

JD Pedrera-Zamorano

Metabolic Bone Diseases Research Group, University of Extremadura, Cáceres, Spain
Correspondence: JD Pedrera-Zamorano Grupo de Investigación en

Enfermedades Metabólicas Óseas, Universidad de Extremadura, Facultad de Enfermería y Terapia Ocupacional, Avd Universidad s/n, 10003-Caceres, Spain Email jpedrera@unex.es

\section{Dear editor}

We read with interest the results of the study from Chang et al ${ }^{1}$ in the International Journal of Nanomedicine. This article shows that curcumin (diferuloymethane), a phenolic compound extracted from the natural plant Curcuma longa L., exerts higher cytotoxicity in osteosarcoma MG-63 cells than in healthy human osteoblasts. Based on the dosages provided by the authors it is hypothesized that with the appropriate drug carriers, curcumin could be delivered to bone tumors and selectively kill osteosarcoma cells without harming healthy osteoblasts. This hypothesis is based in the data provided that claims the dose needed to exert a significant cytotoxicity on osteosarcoma cells was much lower than that needed to exert the same effect on healthy human osteoblasts. The topic of this study is of importance for both cancer and metabolic bone disease fields, we appreciate the methodology of the study, nevertheless we believe that the hypothesis formulated by the authors and their conclusion deserves further comment.

Closer examination of the data raises some concerns regarding the study as the results presented are not in agreement with several previous studies using MG-63 cells and curcumin. Chang et a ${ }^{1}$ presents significant cytotoxicity after MG-63 cell exposure to $5 \mu \mathrm{M}$ curcumin, increased cytotoxicity with $10 \mu \mathrm{M}$, and the highest level of cytotoxicity (less than the $12 \%$ of viability in the cultures) after 24 hours of exposure to $25-100 \mu \mathrm{M}$. Our attention was drawn to the apparent high cytotoxicity of low concentrations of the polyphenol curcumin observed by the authors in the MG-63 cell line-based experiments. Initially, these results appeared to be markedly different from observations made in several laboratories where concentrations of curcumin had lower cytotoxic effects.

In 2008 Walters et $\mathrm{al}^{2}$ reported an $\mathrm{IC}_{50}$ for curcumin after 72 hours of exposure of $19.1 \mu \mathrm{M}$, which was slightly lower than that reported in 2012 by Li et al $^{3}$ of $22.77 \pm 1.70 \mu \mathrm{M}$ (also after 72 hours of exposure). In this last study, ${ }^{3}$ significant cytotoxicity was also reported after 24 hours (similar to the methodology reported by Chang et al) only with dosages over $22.5 \mu \mathrm{M}$ of curcumin. Our group have also reported significant cytotoxicity after MG-63 cell exposure, but only with doses over $20 \mu \mathrm{M}$ after 24 hours. ${ }^{4}$ More recently, and closer to the Chang et al hypothesis, curcumin has been encapsulated in liposomal nanoparticles and has reported to have an $\mathrm{IC}_{50}$ of $23.39 \mu \mathrm{M}$ after 48 hours of exposure of MG-63 cells. ${ }^{5}$

In conclusion, we wish to thank the authors for bringing this apparent lower toxicity of curcumin in healthy osteoblasts to our attention. However, their observations are not in agreement with the literature on MG-63 cells. Clearly further studies are 
required in this area to establish the optimal physiological concentration at which curcumin may exert cytotoxic effects on osteosarcoma cells without cytotoxic sequelae over healthy osteoblasts. In addition it would be beneficial to compare the effects of curcumin on osteosarcoma cell viability across a number of different cell lines.

\section{Disclosure}

The authors report no conflicts of interest in this communication.

\section{References}

1. Chang R, Sun L, Webster TJ. Short communication: selective cytotoxicity of curcumin on osteosarcoma cells compared to healthy osteoblasts. Int J Nanomedicine. 2014;9:461-465.

2. Walters DK, Muff R, Langsam B, Born W, Fuchs B. Cytotoxic effects of curcumin on osteosarcoma cell lines. Invest New Drugs. 2008;26(4): 289-297.
3. Li Y, Zhang J, Ma D, et al. Curcumin inhibits proliferation and invasion of osteosarcoma cells through inactivation of Notch-1 signaling. FEBSJ. 2012;279(12):2247-2259.

4. Moran JM, Roncero-Martin R, Rodriguez-Velasco FJ, et al. Effects of curcumin on the proliferation and mineralization of human osteoblast-like cells: implications of nitric oxide. Int J Mol Sci. 2012; 13(12):16104-16118.

5. Dhule SS, Penfornis P, He J, et al. The combined effect of encapsulating curcumin and C6 ceramide in liposomal nanoparticles against osteosarcoma. Mol Pharm. 2014;11(2):417-27. 


\section{Author's reply \\ Run Chang \\ Thomas J Webster}

Department of Chemical Engineering, Northeastern University, Boston, MA, USA

Correspondence: Thomas J Webster

Department of Chemical Engineering, Northeastern University,

Boston, MA 02II5 USA

Email th.webster@neu.edu

\section{Dear editor}

We thank Moran et al for their interest and comments on our manuscript "Short communication: selective cytotoxicity of curcumin on osteosarcoma cells compared to healthy osteoblasts" recently published in the International Journal of Nanomedicine. ${ }^{1}$ The main point of their letter to the Editor concerns the different cytotoxicity values we have reported for curcumin on osteosarcoma cells (MG-63) compared to other studies. We would like to emphasize that it is very difficult to compare toxicity studies from one group to the next due to the variations in experimental protocols followed. We have observed many variations between our experiments and those experiments cited in the literature by Moran et al. For example, we note that for our study we used the recommended cell culture medium for MG-63 cells as indicated by the vendor (ATCC): Eagle's Minimal Essential Medium (EMEM) supplemented with 10\% fetal bovine serum. In the studies conducted by Walters et $\mathrm{al}^{2}$ and Li et $\mathrm{al}^{3}$ Dulbecco's Modified Eagle's Medium (DMEM) (not EMEM) was used. While this may seem to be a minor point, we would like to point out that there are differences in amino acid composition between EMEM and DMEM that can influence MG-63 cell functions. Specifically, EMEM has more amino acids including L-Alanine, L-Asparagin $\mathrm{H}_{2} \mathrm{O}$, and L-Asparatic Acid. Another major difference between the studies indicated by Moran et al is the manner in which cellular toxicity was determined. In the articles referenced, they expressed MG-63 cell viability by the ratio of optical density of the samples to controls, but this method may not be as precise as the method we followed (converting the optical density to actual cell density by a standard curve) since a few cells could produce moderate optical density. We believe that reporting specific cell densities is a more precise manner to report cellular toxicities. Nonetheless, we feel the value in these studies, although remaining difficult to compare specific curcumin concentration results between them, lies in the general trends observed. For example, in our study, that a different concentration of curcumin can be used to kill osteosarcoma cells than noncancerous osteoblasts. Of course, when translating these results in vivo, we are sure that different toxic concentrations of curcumin will also be observed which needs careful attention for eventual clinical use.

\section{Disclosure}

The authors report no conflicts of interest in this communication.

\section{References}

1. Chang R, Sun L, Webster TJ. Short communication: selective cytotoxicity of curcumin on osteosarcoma cells compared to healthy osteoblasts Int J Nanomedicine. 2014;9:461-465.

2. Walters DK, Muff R, Langsam B, Born W, Fuchs B. Cytotoxic effects of curcumin on osteosarcoma cell lines. Invest New Drugs. 2008; 26(4):289-297.

3. Li Y, Zhang J, Ma D, et al. Curcumin inhibits proliferation and invasion of osteosarcoma cells through inactivation of Notch-1 signaling. FEBS J. 2012;279(12):2247-2259.
International Journal of Nanomedicine

\section{Publish your work in this journal}

The International Journal of Nanomedicine is an international, peerreviewed journal focusing on the application of nanotechnology in diagnostics, therapeutics, and drug delivery systems throughou the biomedical field. This journal is indexed on PubMed Central, MedLine, CAS, SciSearch $®$, Current Contents $® /$ Clinical Medicine,

\section{Dovepress}

Journal Citation Reports/Science Edition, EMBase, Scopus and the Elsevier Bibliographic databases. The manuscript management system is completely online and includes a very quick and fair peer-review system, which is all easy to use. Visit http://www.dovepress.com/ testimonials.php to read real quotes from published authors. 